\title{
Innovation, Procurement and Construction Industry Development
}

Gerard de Valence, (University of Technology, Sydney, Australia)

\begin{abstract}
The implications for analysis of innovation in construction of theoretical developments in industrial organisation are considered in this research, as an attempt to outline a new approach to construction innovation incorporating the ideas found in knowledge based, technology centred models. The paper firstly summarises characteristics of the construction industry, focusing on their effects on innovation, before surveying some of the ideas about the sources of innovation and the expansion and application of knowledge. Construction can be seen as an industry with limited scope for knowledge externalities, where the procurement methods used by the industry's clients do not pay for innovation. The following discussion uses recent developments in the research on the economics of innovation and industrial organization theory, such as research intensity and the endogenous sunk costs in competitive, fragmented, low research intensity industries. The effects on R\&D of procurement methods and on industry structure are discussed, with a focus on the appropriability of innovations and the role of the client on the Heathrow Terminal 5 project. The paper concludes that the procurement methods used for building and construction projects appears to be a determining factor in the level of innovation in the construction industry.
\end{abstract}

Keywords: Construction, Innovation, Research intensity, Procurement, Clients

\section{Introduction}

Whilst the construction industry has developed over the years there is increasing pressure to become more innovative and deliver better value for money for clients. However there are certain characteristics of the industry that appear to slow progress and make innovation difficult, because the particular interplay of technological change and industry adaptation and development has characteristics unique to building construction.

Product innovation is the introduction of new materials and/or components into the constructed product, and there has been a great deal of this form of innovation in recent decades. Its counterpart, process innovation, is generally more difficult to manage and deals with the development of new organisational structures, management methods, and other techniques or actions that improve business processes and competitiveness. The construction industry's sense of its history, with strong craft traditions and focus on individual projects, has significantly affected efforts to improve the constructed product in terms of cost, time and quality (Woudhuysen and Abley 2004).

Innovation in the construction industry has been a focus of research since Rosefielde and Mills (1979). By the commonly accepted measures of innovation, such as patents, technological research papers, introduction of new products or process improvements (Freeman and Soete 1997: 7-8), the construction industry has a record of very low identifiable innovation and has thus been viewed as a technological laggard, with a slower adoption of new technology and lower levels of research and development (R\&D) and innovation than other industries (Miozzo and Dewick 2002). Although there are good arguments to the contrary, Winch (2003) for example argues that the comparison between construction and manufacturing is inherently biased against construction if R\&D is used as 
the criteria, this is nonetheless a widely held view. One issue that this debate raises is whether the determinants of innovation and the rate of technological advancement in construction are well understood. Using Hobday's (1998) ideas on innovation in complex systems, as developed by Gann and Salter (2000), it is may be that many of the significant factors influencing innovation and development of technological capabilities in construction are found in aspects of custom and practice that are taken for granted by the industry.

The purpose of this paper is to look at the R\&D intensity and level of innovation that characterizes the construction industry, and relate these to the procurement systems and market structure in the industry. This discussion covers the characteristics of the construction industry and innovation, the relationship between $R \& D$ and procurement, $R \& D$ and industry structure, and the difficulty of achieving returns on R\&D in an industry that is fragmented and highly dispersed. The implications of these factors for construction industry development are discussed.

\section{Industry Characteristics and R\&D}

Construction was described as a heterogeneous, widely dispersed industry, where no two products share the same characteristics, with limited scope for learning curve benefits and productivity growth associated with them by Cassimatis (1970). Construction offers a customised product with unique characteristics: immobility, complexity, durability, costliness, and a high risk of failure (Nam and Tatum 1988). There is little direct repetition, individual projects are designed and built to serve a particular function or meet a special requirement. Although many design and process skills are commonly used, the outputs differ and this impacts substantially on the efficiency and economies of scale of the construction process, which in turn significantly influences innovation and technological development rates (Hobday 2000).

Tatum's papers focused on advantages and constraints to innovation in construction, and despite being two decades old this work captures many of the key features of the discussion raised by more recent efforts such as Reichstein et. al. (2005), Fairclough (2002), or Slaughter (1998). Tatum (1986) identified seven features of the construction industry that he claimed as advantages for innovation. Construction project teams are presented with high levels of necessity and challenge, which promotes innovation by forcing examination of new technologies for each project. Integration of engineering, design and construction can simplify the construction process and decrease cost. The low capital investment typical of construction firms allows high flexibility for the adoption of new technologies. A pool of technologically experienced personnel provides depth of knowledge. The strong emphasis on process limits barriers to imitation, because new processes can spread rapidly without patent restraints (but this may also discourage innovation). Lastly, construction production processes do not create rigid restraints (Slaughter 1993 generally followed this approach).

Nam and Tatum (1988) compared the characteristics of constructed products with those of manufacturing, arguing that five specific differences limit the development of construction technology. These are: immobility, complexity, durability, costliness and high degree of social responsibility. Their effect is to create conditions for production processes that result in a 'locked system' in which innovation becomes difficult (Reichstein et. al. 2005 also used some of these characteristics in their analysis, which reached a similar conclusion). Dubois and Gadde (2002) also argued the temporary character of project-based construction hindered innovation.

Five other characteristics of the construction industry were later identified by Tatum (1989) as being constraints to innovation. The low capital intensity of the industry limits its interest in investment for automation. If a firm has adequate market share and profitability then pressure to innovate is reduced. The institutional framework is not supportive of innovation (the number of firms, the legal incentives for technological inertia, regulatory influences, and

de Valence, G (2010) 'Innovation, procurement, construction industry development', Australasian Journal of Construction Economics and Building, 10 (4) 50-59 
craft organization of labour). Building cycle volatility affects capital investment and economies of scale, and suppliers have not created technological improvements in the equipment and tools used by construction.

Tatum's analysis is descriptive of the construction industry and remains representative of much of the research on models of innovation in the industry to date, but lacks an explanation of how innovation occurs, or could occur in the industry. Reichstein et. al. (2005) identify what they call 'organisational liabilities' for innovation and low demand for innovation from clients and the market. Similarly, Manly and Mcfallan (2006) found the business strategies of individual firms more important than markets or marketing strategies for innovating firms or organisations.

Gann (2003: 554) cites Bowley (1960) as showing that construction is an adopter of innovations from other industries, rather than a source of innovation. Bowley's work "shows that demand for new types of buildings is usually more important in stimulating radical technical and organizational innovation than the need to erect better and cheaper buildings to accommodate existing functions. She also shows that innovation in basic materials, originating from outside the building industry and with markets far wider, play an important role in the evolution of construction."

None of this provides an explanation of the construction industry's record of innovation that is grounded in the broader theories of innovation available, in order to identify the most important factors at work. The industry characteristics approach, even when done with the detail of Manley and Kajewski (2011) for example, works better at the level of firms rather than the industry. This paper therefore develops a model of construction innovation in a revised framework, identifying procurement methods as the driver or inhibitor of innovation. The argument is on two levels. Firstly, at the level of industry structure, the relationship between innovation and concentration is discussed. The issue here is whether the research intensity of construction is an outcome of industry competition rather than a requirement, as in high research intensity industries. Secondly, the issues of appropriateness of research and innovation revenues and treatment of knowledge externalities are considered in the context of procurement methods used.

\section{Characteristics of Innovation and R\&D}

Although not in a formal model, Schumpeter (1942) argued economic development is a dynamic process, occurring discontinuously over time as his 'perennial gales of creative destruction' drive ongoing change of the economic structure, driven by waves of product innovation that sweep away old industries, old goods, and old services (Schumpeter 1942: 81-87). As the pace of diffusion of a particular innovation slackens so will the rate of economic development. In the search for profits, a better innovation will be created, allowing the development process to repeat the cycle. The main agents for change were entrepreneurs, as distinct from capitalists, innovators, and managers of production and distribution.

Two ideas of Schumpeter are particularly important in the context of this paper: the impact of economic incentives on the development of new technology, which makes clear the endogenous nature of the growth process; and, linkages between investment and other areas of the economy through diffusion of technologies. The development of new technology has significant costs, and Schumpeter's emphasised the importance of the rate of return in determining investments in innovations. Schumpeter recognised that investment in R\&D was a calculated risk for the firm but, if successful, a benefit to society as a whole.

The concept of linkages and diffusion was used to develop a theory of growth through leading industrial sectors with strong linkages to other industries. Initial investment creates knowledge for the investor and others to make more informed decisions about future

de Valence, G (2010) 'Innovation, procurement, construction industry development', Australasian Journal of Construction Economics and Building, 10 (4) 50-59 
investments. The 'leading sectors' in this theory are those that generate the most externalities and where diffusion of technologies to other industries occurs most rapidly (Romer 1990). This 'new growth theory' made technology endogenous by bringing technological progress inside these models and allowing innovators to capture the benefits of their R\&D.

\section{Research in Intensity}

There are major differences between industries in rates of both technological progress and productivity growth. Efforts have been made to find both theoretical and empirical explanations of the factors that drive these differences, and one explanation is $R \& D$ intensity, or the degree of innovation that is found in one industry compared to another. Research intensity is typically measured by R\&D as a percentage of sales or income.

R\&D intensity in an industry is determined by two key variables. One is "technological opportunity", which determines the productivity of R\&D and the opportunities that are available for innovation. The other is the ability of innovating firms to "appropriate" a significant share of the economic value created by innovation, or to capture the externalities created through new knowledge. However, although both these variables influence R\&D intensity of firms in an industry, only technological opportunity will affect the rate of technological advance in an industry in the long-run, even if both opportunity and appropriability influence R\&D intensity .

"Differences across industries in their R\&D intensities tend to be quite durable. This suggests that, to the extent that these are the major determining variables, differences across industries and technological opportunities and inappropriability conditions tend to be persistent." (Nelson and Wolff 1997: 207). Nelson and Wolff propose cross industry differences in technological opportunities are due to R\&D opportunities differing between industries. In turn, differences between industries in technological progress will be driven by differences in R\&D intensity, appropriability and available opportunities. Their theory is that industries with high $R \& D$ intensity and technological opportunity must have a high rate of new technological opportunities to make up for those that are being exhausted (see Nelson and Winter 1982).

In the industrial organization or industry economics literature, industries are usually seen in terms of a number of firms which advance along a single technological trajectory, and these firms compete in enhancing the quality of their individual versions of the same basic product (homogeneity of product). In this case, firms make decisions on how much R\&D to finance, and apply that R\&D to product development. This view fits some industries well, however many industries encompass several groups of products rather than a large number of versions of a single product (Sutton 1991). The products may be close substitutes in consumption, but embody different technologies, so R\&D projects that enhance products in one group may generate huge spillovers for products in other groups.

Such complex overlapping patterns of substitutability have bedeviled industrial organization analysis for decades, since Chamberlin (1932) first developed the definition of an industry as limited by the scope for substitution between products, where industries were defined by their product. If industries are broken into separate sub-industries in order to address this problem, the choice in R\&D spending can be between any number of technologies for the development of different groups of products. The products may be close or distant substitutes for products of firms on other technological trajectories. Both of these linkages operate on the demand side. When the linkages are strong they reflect the presence of scope economies in R\&D, where the linkages are weak these scope economies will be absent and there will be a low degree of substitution across sub-markets.

de Valence, G (2010) 'Innovation, procurement, construction industry development', Australasian Journal of Construction Economics and Building, 10 (4) 50-59 


\section{R\&D and Market Structure}

The degree of monopoly power exercised by the largest firms in an industry is expressed in the concentration ratio, which is the degree to which an industry is dominated by the largest firms. Typically the concentration ratio uses the largest four firms in an industry, ranked by market share or sales as a percentage of total industry sales. The definition of the concentration ratio is the percentage of industry total sales (other measures are capacity, output, employment or value added) accounted for by the largest firms. The extent of control over prices is determined by the intensity of competition in a market, which is, in turn, determined by entry barriers, the number of firms and type of product. The effects of competition from new firms and new ideas drive change and development. Thus industries with rapid changes in technology and/or aggressive new entrants are likely to be those where competition drives firms toward greater efficiencies and innovative methods.

Sutton (1999) in his development of a theory of market structure and concentration, suggests the effect of $R \& D$ spending on the technological trajectory of industries is crucial. Where the degree of substitutability across products associated with different R\&D trajectories is high, concentration will necessarily be high, because if all firms have a low market share an increase in R\&D spending will be profitable, and the high spending firm can capture sales from low spending rivals on its own trajectory and on others. Sutton shows that under these circumstances, the number of trajectories along which firms will operate is small, since low spending firms are vulnerable to increases in R\&D spending by rivals. On the other hand, if the degree of substitution across products is low, then in spite of the effectiveness of $R \& D$ spending, concentration may be low. "This can only happen if there are many product groups, associated with different independent R\&D trajectories. Here, escalation yields poor returns, since outspending rivals can lead only to the capture of sales from products in a single, small product group" (Sutton 1999: 13).

In Sutton's analysis it turns out that industries or sub-industries with a low R\&D to sales ratio can have a low level of concentration, and this can continue indefinitely. The industries where there are a large number of firms in an increasing market, characterised by buyers who place different relative weights on different aspects of technical performance (product attributes), and many alternative technologies are available for those products, leads to a market where there is an indefinite number of firms, each with a small market share. For an industry with low $R \& D$ spending, Sutton's theory predicts the concentration ratio will be low and that the level of concentration will decrease as the size of the market increases. For industries where the R\&D to sales ratio exceeds a high threshold value, Sutton's theory predicts concentration will increase as the spending on R\&D increases. In a low R\&D intensity industry, the market share of the largest firm will be relatively small, in a high R\&D intensity industry the market share of the largest firm can be very high (Sutton 1999: 14-16).

\section{Procurement and Innovation}

How can the key issues identified here be addressed? The roles of appropriability, patterns of substitutability, the importance of R\&D intensity in determining concentration and the risks associated with innovation for clients, these are a set of mutually reinforcing factors that work against innovation and R\&D for many, perhaps the majority of construction industry firms. The answer proposed here is that the best way to increase innovation lies in the methods and systems used to procure building and construction projects. That is a broad generalisation that needs to be supported by evidence and argument, so the discussion below covers two cases where procurement and innovation can be seen to be closely related.

The first case is the difference between traditional procurement and design and build (D\&B). For the building and construction industry the methods used for tendering and procurement of projects are important determinants of the level and form of competition in the industry,

de Valence, G (2010) 'Innovation, procurement, construction industry development', Australasian Journal of Construction Economics and Building, 10 (4) 50-59 
and distinguish the industry from many others where competition is through marketing campaigns, new products and so on (de Valence 2011).

Craig (1997a) concludes tendering rules or codes have been developed to maintain the integrity of the bidding process, not to encourage innovation. Craig (1997b) then argues that 'alternative tenders' are potentially valuable to both clients and contractors, and to society at large. Contractors can make novel proposals to owners, and society benefits from such innovation.

Craig (2000) develops these issues and asks three questions on procurement and innovation. The first is whether tendering processes encourage innovation. He suggests the essential of tendering is that all tenderers are to be treated equally, and that contract award criteria are established in advance and known by all parties, thus creating a transparent award process. Tendering rules produce direct price competition for a specified product. The question then becomes: can traditional tendering processes permit innovation? His answer is that a successful tenderer's scope to be innovative is very limited. There is opportunity to maximise profits within the tender price by novel ways of organising work or 'bid shopping' to drive down subcontract prices. But bidders are not asked to put forward design suggestions, there are no criteria for evaluation of novel proposals, and tenderers cannot be treated equally if one is preferred on an alternative tender, which is non-conforming in terms of the original invitation.

Finally, Craig (2000) asks whether D\&B as a procurement system more easily permits innovation. The point is made that using the tender process to competitively evaluate design, capability, time and cost is not easy, and the integrity of the process has to be safeguarded. Craig concludes that the traditional tendering process for building works does not encourage design innovation by tenderers, but it has always been possible for tenderers to seek competitive advantage through novel construction methods. The potential for innovation in $D \& B$ is there, but may not be easy to realise.

This argument by Craig can be extended to other non-traditional forms of procurement where the client has the opportunity to encourage innovative solutions. These would include build, own, operate (BOO), and build and maintain (B\&M) contracts, where the long-term performance and maintenance costs of the facility are important factors in design decisions. This also applies to PPP or PFI projects, and other concessions that transfer back to the government at the end of the contract, with condition specifications to be met.

\section{Clients and Innovation}

Ivory (2005) argued clients will avoid risk associated with innovation on their projects. He found clients act as a significant barrier to innovation because they are concerned about both construction budgets and operating costs, and do not think they will benefit significantly from a successful innovation. Further, he suggests clients carry a 'disproportionate' share of innovation risk and as a result "should not be routinely expected to take on the risks (in terms of cost and time overruns or poor building performance) and costs associated with innovation"(2005: 868-9).

While Ivory's argument might be generally true, the exceptions prove the rule. Therefore the second case looked at here is the Heathrow Terminal 5 (T5) project. This project demonstrates the effect a determined client with a clear strategy to encourage innovation in order to improve performance can have. The project has been extensively documented elsewhere (including the book by Doherty 2008), so this discussion visits the main points and provides references for the supporting detail.

In its role as the client BAA took on all the risk for the $£ 4.3$ billion project, under the unique T5 Agreement that the 60 first tier contractors signed. In total, 15,000 suppliers were

de Valence, G (2010) 'Innovation, procurement, construction industry development', Australasian Journal of Construction Economics and Building, 10 (4) 50-59 
involved. The overall project was divided into 147 sub-projects, with an integrated team led by BAA responsible for each one. Unlike the majority of megaprojects, T5 was delivered on time and on budget (Wolstenholme, Fugeman and Hammond 2008). To achieve its objectives BAA implemented a comprehensive strategy to change both its own capabilities and those of its main suppliers. Brady et al. (2007) looked at the role of BAA, how it applied lessons from previous projects, its interaction with the networks of firms involved and how their capabilities were developed. Consultants were sent by BAA into the major suppliers to identify ways and means to improve their efficiency and the Agreement included gain sharing when cost targets were bettered (Davies, Gann and Douglas 2009).

The key relevant point about T5 is that innovations in many forms were actively sought out and developed. These included product innovations in off-site fabrication such as the roof structure (Franklin and Hulme 2008), technological innovations such as the tunnelling process and equipment (Williams 2008), process innovations such as the two logistics centres (Potts 2008), and management innovations such as the insurance provisions and incentives built into the T5 Agreement, Deakin and Koukiadaki (2009) detail the industrial relations aspects of the project.

Caldwell, Roehrich and Davies (2009) suggest that the risk associated with these large, complex projects can provide the motivation for clients to pursue and reward innovation by contractors and suppliers. By taking on and actively managing project risk, BAA was able to purse a strategy of rewarding performance enhanced by innovations from all participants. Following on from T5 is the wider case for alliance contracting. In particular, the expectation of knowledge sharing by the participants and the effect of working in integrated teams (see Gil 2009 in particular for detail on, and analysis of, the workings and outcomes of the many aspects of the alliance relationships on T5).

\section{Conclusion}

Tatum's $(1986,1989)$ characteristics of the construction industry represent a widely applied model of construction industry innovation. From the viewpoint of the economics of innovation and endogenous growth theories, most of these characteristics are not drivers of innovation, and such a model of the industry therefore excludes the main sources of innovation identified by those theories. This paper has explored the applicability of some of these ideas to construction innovation.

The comparatively low level of investment in innovation appears to be a result of construction being a mature, highly competitive industry with limited scope for knowledge externalities. In particular, the combination of individual procurement of heterogeneous products by clients and increasing specialisation and sub-contracting within the industry significantly limits the scope and potential for positive knowledge externalities, as argued by Dubois and Gadde (2002). This is despite the industry's project-based form of organisation (Hobday 2000) and the opportunities for innovation in service industry firms (Gann and Salter 2000).

Research into the economics of innovation has shown investment in R\&D has a significant effect on industry growth, but the effect of R\&D is most pronounced where technological opportunity is high. The general results of Sutton's research can be applied to the construction industry where most of the technical advances of the last four decades have come from the materials suppliers and equipment manufacturers, who have been responsible for the R\&D leading to the introduction of new products and equipment, such as building facades, power tools and lifts. Many generic technologies such as IT and telecommunications have also impacted on the building and construction process, particularly in the design professions, but at a significantly slower pace than in other industries such as retailing and finance.

de Valence, G (2010) 'Innovation, procurement, construction industry development', Australasian Journal of Construction Economics and Building, 10 (4) 50-59 
The act of investment in innovation, and the associated human and physical capital, generates knowledge externalities. However, the traditional tendering process used by construction industry clients has them typically select on price and not pay for innovation in particular or intellectual property in general. This does not allow tenderers to appropriate the benefits of knowledge, thus removing the main incentive to innovation identified by endogenous growth theory. As argued by Craig, this has two main causes, firstly, an innovative tender will probably not be a conforming tender. Secondly, the client gets the benefit of the design and/or construct solutions of all tenderers, and can revise the project or recall tenders.

Procurement has thus become a more central issue to the industry because the method of project procurement used by the client determines the nature of competition in the industry, and this in turn determines the role and extent of innovation on their projects. BAA showed on T5 that innovation can be a strategic option on complex projects, if the client is prepared to manage the risks involved. One of the striking features of the T5 project was the incentive structure produced a wide range of innovations across many different sub-projects that made up the project as a whole.

More generally, the move away from traditional procurement systems will have significant effects on innovation. Because the traditional design-bid-build method does not allow for capture of intellectual property and knowledge externalities by contractors in their tenders, there was a perverse disincentive to innovate. With the increased use of non-traditional procurement methods such as design and construct, D\&B, build, own, operate, and build and maintain, this disincentive is removed and firms can more easily appropriate the benefits of innovation and R\&D over the extended life of these contracts or concessions.

The influence of procurement methods appears to be a determining factor in the level of innovation in the construction industry, and the significance of increased use of alternative forms of procurement lies in the opportunity for increased R\&D and innovation they provide. In the past, the level of innovation may have been an outcome of industry structure, not a determinant. However a more R\&D intensive industry would tend toward having structure determined by research intensity. As R\&D expenditure increases the potential level of concentration also rises, and this should be seen in the sectors of the industry where large, complex projects that require intellectual property and innovation are common. The interplay between these factors may determine the eventual number of large firms in construction industry sectors where national, international and global contractors compete.

\section{References}

Brady, T., Davies, A., Gann, D. and Rush, H. (2007) Learning to Manage Mega Projects: The case of BAA and Heathrow Terminal 5, Project Perspectives, XXIX, 32-39

Bowley, M., (1960) Innovation in Building Materials, London, Gerald Duckworth

Cassimatis, P. (1970) Economics of the Construction Industry, Conference Board, Studies in Business Economics No. 111

Chamberlin, E. (1932) Theory of Monopolistic Competition, 1st Ed, Cambridge, Massachusetts, Harvard University Press

Craig, R. (1997a) Competitive Advantage through Tendering Innovation, Cll Australia, Fourth Annual Conference, Melbourne

Craig, R. (1997b) The 'Tendering Contract': Fairness, Equality and Innovation, in Davidson, C. and Mequid, T. (eds) Procurement - A key to Innovation, CIB W92 Publication 203, 91100

Craig, R. (2000) Competitive Advantage through Tendering Innovation, Australian Construction Law Newsletter, 70, 3-14

de Valence, G (2010) 'Innovation, procurement, construction industry development', Australasian Journal of Construction Economics and Building, 10 (4) 50-59 
Caldwell, N., Roehrich, J. and Davies, A. (2009) Procuring complex performance in construction: London Heathrow Terminal 5 and a Private Finance Initiative Hospital, Journal of Purchasing \& Supply Management, 15

Davies A., Gann D. And Douglas T. (2009) Innovation in Megaprojects: Systems Integration at Heathrow Terminal 5, California Management Review, 51, 101-125

Deakin, S. and Koukiadaki, A. (2009) 'Governance processes, labour-management partnership and employee voice in the construction of Heathrow T5', Industrial Law Journal, 38 (4): 365-389

de Valence, G. (2011) Competition and barriers to entry in the construction industry, in Modern Construction Economics: Theory and Application, in de Valence (Ed.), Oxford, Taylor \& Francis, 100-116

Doherty, S. (2008) Heathrow's Terminal 5: History in the making, London, Wiley

Dubois, A. and Gadde, L.-E. (2002) The construction industry as a loosely coupled system: implications for productivity and innovation, Construction Management and Economics, 20, 621-631

Fairclough, J. (2002) Innovation in the Construction Industry - a Review of Government R\&D Policies and Practices, Department of Trade and Industry, London

Frankland, W. and Hulme, P. (2008) T5A roof: the abutment first run study, Proceedings of the ICE - Structures and Buildings, 161 (2), $57-64$. Accessed on $24^{\text {th }}$ September 2010 from http://www.icevirtuallibrary.com/content/article/10.1680/stbu.2008.161.2.57

Freeman, C. and Soete, L. (1997) Economics of Industrial Innovation. Cambridge, Mass., MIT Press

Gann, D. (2003) Guest editorial: innovation in the built environment, Construction Management and Economics, 21, 553-5

Gann, D. and Salter, A. (2000) Innovation in project-based service-enhanced: the construction of complex products and systems, Research Policy 29, 955-972

Gil, N. (2009) Developing Cooperative project client-supplier relationships: How much to expect from relational contracts, California Management Review, Winter, 144-169

Hobday, M. (2000) The project-based organisation: an ideal form for managing complex products and systems? Research Policy, 29, 871-893

Hobday, M. (1998) Product complexity, innovation and industrial organisation, Research Policy, 26, 689-710

Ivory, C. (2005) The cult of customer responsiveness: is design innovation the price of a client-focused construction industry? Construction Management and Economics, 23, 861870

Manley, K. and Kajewski, S. (2011) Innovation in construction: A case study of the Australian context, in Modern Construction Economics: Theory and Application, de Valence (Ed.), Oxford, Taylor \& Francis, 135-153

Manley, K. and Mcfallan, S. (2006) Exploring the drivers of firm-level innovation in the construction industry, Construction Management and Economics, 24, 911-920

Miozzo, M. and Derwick, P. (2002) Building competitive advantage: innovation and corporate governance in European construction, Research Policy, 31 (6), 989-1008

Nam, C. and Tatum, C. (1988) Major characteristics of constructed products and resulting limitation of construction technology, Construction Management and Economics, 6 (2), 13348

de Valence, G (2010) 'Innovation, procurement, construction industry development', Australasian Journal of Construction Economics and Building, 10 (4) 50-59 
Nelson, R. and Winter, S. (1982) An Evolutionary Theory of Economic Change, Cambridge, Massachusetts, Harvard University Press

Nelson, R. and Wolff, E. (1997) "Factors Behind Cross-Industry Differences in Technical Progress". Structural Change and Economic Dynamics, 8 (2) 205-220

Potts, K. (2008) From Heathrow Express to Heathrow Terminal 5: BAA's development of Supply Chain Management, in Pryke, S. (Ed.) Construction Supply Chain Management, Oxford, Blackwell

Reichstein, T., Salter, A. J. and Gann, D. (2005) Last among equals: a comparison of innovation in construction, services and manufacturing in the UK, Construction Management and Economics, 23, 631-644

Romer, P. (1990) Endogenous Technological Change, Journal of Political Economy, 98, 71102

Rosefielde, S. and Mills, D.Q. (1979) 'Is Construction Technologically Stagnant ' in Lange, J.E. and Mills (Eds.) The Construction Industry: Balance Wheel of the Economy, Lexington, Mass, Lexington Books

Schumpeter, J. (1942) Capitalism, Socialism and Democracy, New York, Harper

Slaughter, S. (1993) Builders as sources of construction innovation, Journal of Construction Engineering and Management, 119 (3), 532-49

Slaughter, S. (1998) Models of construction innovation. Journal of Construction Engineering and Management, 124 (30), 226-31

Sutton, J. (1991) Sunk Costs and Market Structure, Cambridge, Massachusetts, MIT Press

Sutton, J. (1999) Technology and Market Structure. Cambridge, Massachusetts, MIT Press

Tatum, C. (1986) Potential Mechanisms for Construction Innovation, Journal of Construction Engineering and Management, ASCE, 112 (2)

Tatum, C. (1989) Organising to Increase Innovation in Construction Firms, Journal of Construction Engineering and Management, ASCE, 115 (4)

Winch, G. (2003) How innovative is construction? Comparing aggregated data on construction innovation and other sectors - a case of apples and pears, Construction Management and Economics, 21, 651-654

Williams, I. (2008) Tunnelled underground infrastructure, Proceedings of the ICE - Civil Engineering, 161 (5), $30-37$. Accessed on $24^{\text {th }}$ September 2010 from http://www.icevirtuallibrary.com/content/article/10.1680/cien.2007.161.5.30

Wolstenholme, A., Fugeman, I. and Hammond, F. (2008) Heathrow Terminal 5: delivery strategy. Proceedings of the ICE - Civil Engineering, 161(5), 10-15. Accessed $18^{\text {th }}$ Sep. 2010 from http://www.icevirtuallibrary.com/content/article/10.1680/cien.2007.161.5.10

Woudhuysen, J. and Abley. I. (2004) Why is Construction so Backward? Chichester, John Wiley \& Sons 